\title{
Timing Quality for New Generation Networks
}

\author{
S.V. Melnik ${ }^{1}$ \\ Moscow Technical University of Communications and Informatics; \\ Central Science Research Telecommunication Institute \\ N.I. Smirnov ${ }^{2}$ \\ Moscow Technical University of Communications and Informatics \\ Moscow, Russia \\ 1'svmelnik@bk.ru, 22smirnov.ni@yandex.ru
}

\begin{abstract}
New generation networks deployment has one of the perspective directions the concept of the Internet of Everything (IoE) [3]. Rendering services in the IoE networks require providing a stable time scale with an accuracy of definition not less than $1 \mathrm{~ms}$, and at operation of applications of the tactile Internet not less than 1 microsec. As in the current legislation are absent obligatory requirements to the accuracy of definition of time in the $I 0 E$ networks, the mechanism of additional certification is required. Additional certification of production and services is the mechanism for check of correctness of the made decisions and current state of projects on production of new hi-tech production and services. Existence of the certificate of Digital Innovations system can be criterion of providing a level of quality and necessary amount of works by results of the project.
\end{abstract}

Key words: digital economy, certification, type approval.

\section{INTRODUCTION}

5G mobile communication networks, technologies of the Industrial Internet of Things (IIoT), Tactile Internet of Things (TIoT), Software Defined networks (SDN) with Network Functions Virtualization (NFV), and Big Data systems have to become a technological basis for implementation of the "Digital Economy of the Russian Federation" program. All these technologies unite Internet of Everything (IoE) concept. For sure, work of the technologies connected with high reliability and providing the minimum delay at distribution of signals tough standards to providing a timeline are required. So, in networks of the IIoT, at remote control of the infrastructure equipment and objects, at the organization of the pilotless movement of vehicles at speeds up to $60 \mathrm{~km} / \mathrm{h}$, ensuring accuracy of a timeline $1 \mathrm{~ms}$ is required. Ensuring management of the pilotless movement of vehicles at speeds more than 80 $\mathrm{km} / \mathrm{h}$, controls of unmanned aerial vehicles and railway objects require providing a time scale with an accuracy of 1 microsec. There is one more aspect of use of high-precision devices for ensuring exact time is a TIoT. In such appendices as a telemedicine, in case of carrying out remote surgical influence, the accuracy of time of 1 microsec on condition of the maximum delay of transfer of a package of $1 \mathrm{~ms}$ is required.
If to consider all these technological directions in the light of the operating regulatory legal base, there are collisions. It is connected with that the main existing normative legal documents, such as the law No. 126-FZ "About communication" of 07.07.2003 and the law No. 184-FZ of 27.12.2002 "On technical regulation" are accepted more than 15 years ago. Then nobody could assume that in the near future technologies of pilotless driving of cars will begin to take root that the large cities will become almost completely covered not only networks of mobile communication with high-speed data transmission, but also full video surveillance with possibility of a face recognition. Become objects of interaction of communication networks not only natural and legal entities, but also inanimate objects. Information processing becomes spaced (Cloudy technologies - Cloud computing) with part of functions which are transferred to local networks (Foggy calculations - Fog computing).

It turns out that presentation of obligatory requirements to means of communication at the level of technical characteristics (Network Performance) isn't enough for ensuring integrity, stability and safety of networks of new generation. It is necessary to impose additional requirements which have to concern not only means of communication, but also services of a digital network on level of service (Quality of Service), and also at the level of external perception of communication services (Quality of Experience).

It is clear that we are expected by deep processing of current laws and bylaws, but this process can take a lot of time, and it will always lag behind the real requirements connected with the advancing technological development. As the adopted laws and bylaws have to rely on the operating accepted norms and standards and can't advance standardization.

The collision consists that in the absence of the existing obligatory requirements, laws and bylaws, it is necessary to realize the most part of the "Digital Economy of the Russian Federation" program and to be sure that all invested funds did not go to waste. It is about means from the state budget and the reporting for their expenditure are regulated by the current legislation.

Certainly, implementation of the "Digital Economy of the Russian Federation" program requires scientific approach. First of all it is necessary to develop the concept of creation of a 
modern national network of telecommunication within implementation of the program of development of Digital economy of the Russian Federation. This concept differs from the general program of development of communication networks of the Russian Federation in that it concerns the certain direction which is the "Digital Economy of the Russian Federation" program with public financing. The mechanism of public financing means other level of control and supervision of work than financing from commercial structures. Therefore, measures of installation of requirements to networks, means and communication services on the basis of which the decision on their suitability for implementation of the "Digital Economy of the Russian Federation" program are made have to be developed.

Before emergence of the approved international standards to networks of mobile communication 5G, IIoT, TIoT, SDN/NFV, BigData and to other technologies of new generation, it is impossible to accept requirements for obligatory certification of production and services. Meanwhile, skilled and commercial operation of the corresponding networks and constructions is necessary to avoid possible technological lag. It is necessary to provide the mechanism of additional certification of production and services which will extend only on the objects planned for use at implementation of the "Digital Economy of the Russian Federation" program.

Additional certification allows to impose requirements to again developed products and services before emergence of obligatory requirements.

For assistance of implementation of the "Digital Economy of the Russian Federation" program approved by the order of the Government of the Russian Federation of July 28, 2017 No. 1632-r [2] under the auspices of the International academy of communication system of certification "Digital Innovations" is created.

Additional certification allows not only to estimate efficiency of the measures undertaken for implementation of the Program but also to certify quality of synchronization of time.

Additional certification of production and services is the mechanism for check of correctness of the made decisions and current state of projects on production of new hi-tech production and services.

Existence of the certificate of Digital Innovations system can be a criterion of performance of quality and amount of works by results of the project, and also qualities of definition of time for the IoE networks.

It is expedient to use the certificate of Digital Innovations system, as means of confirmation of the characteristics of production which are not regulated by the existing obligatory requirements [3].

Requirements at additional certification can be both softer, and more rigid than at obligatory.

Certification in Digital Innovations system is more flexible and universal tool than obligatory confirmation of compliance. Certification in Digital Innovations system is irreplaceable at implementation of the concept of creation of the new environment for production and services within the program of digital economy of the Russian Federation [4-7].

\section{THE CENTRALIZED SCHEME OF TIME SYNCHRONIZATION}

The problem of time synchronization can be solved by accession to the remote server of time having an exit to the source synchronized with the State standard, for example, of GNSS GLONASS. The centralized architecture of time synchronization in a capillary network is shown in Figure 1. However, such method of the decision determines that it is necessary to guarantee that when receiving signals of time, the distortion involving increase in probability of a mistake will not arise in each network node.

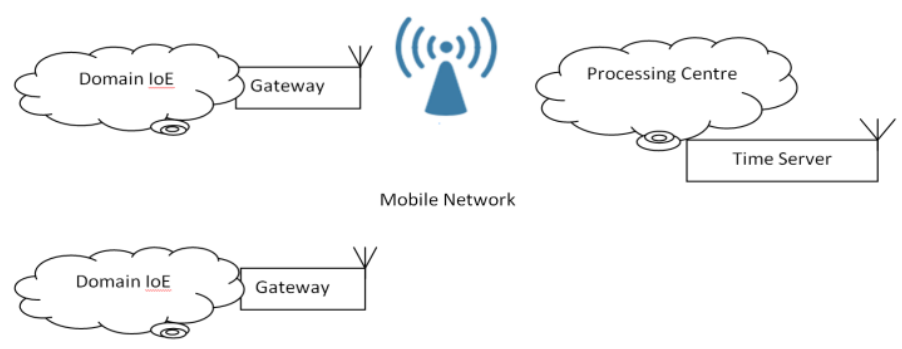

Fig. 1. The centralized scheme of time synchronization

\section{THE DISTRIBUTED SCHEME OF TIME SYNCHRONIZATION}

In a network with a large number of IoE domains, some of which can be on considerable removal from the center of information processing, the centralized scheme of providing the uniform temporary is not effective.

By analogy with the methods stated in [6;7], it is possible to offer the distributed architecture for time synchronization in a IoE network (Fig. 2).

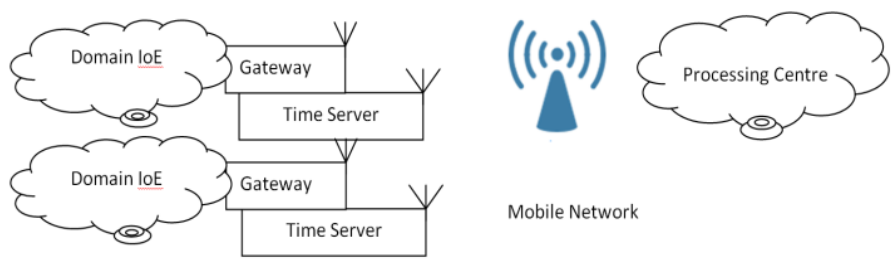

Fig. 2. The distributed scheme of time synchronization

In the distributed scheme of ensuring unity and accuracy of a time scale in a IoE network, we use the compact server of time with the GPS/GLONASS receiver connected to a lock of the IoE domain. At such version of the solution of a problem of time synchronization, we can guarantee the accuracy of an order of units of nanoseconds. This accuracy of temporary synchronization has enough for the solution of any technological task in which interests the capillary network is under construction. This mechanism, especially effective, will be when using in systems of a dual purpose which impose increased requirements on reliability.

\section{TIMING QUALITY DETECTION AND USING FAST BLOCKCHAIN ALGORITHM}

In system of certification "Digital Innovations" essentially new technique of certification of quality of time synchronization is developed. This technique is based on the block chain algorithm when processing the temporary tags generated by the equipment by STC KOMSET. When the quality control mechanism of synchronization initializing, each tag which is generated by the server of time by STC KOMSET is added to the block in the field of Time. Blocks are processed in system of processing of inquiries, a control system of servers and on transit hosts of the estimated company. Thus, it is formed Blockchain, excluding falsification of data on determination of quality of 
synchronization. In the measurements scheme we use new kind of blockchain algorithm in Standard Blockchain algorithm using timing from Internet clock with accuracy 0,1 sec. Usually Blockchain looks like in the Fig. 3.

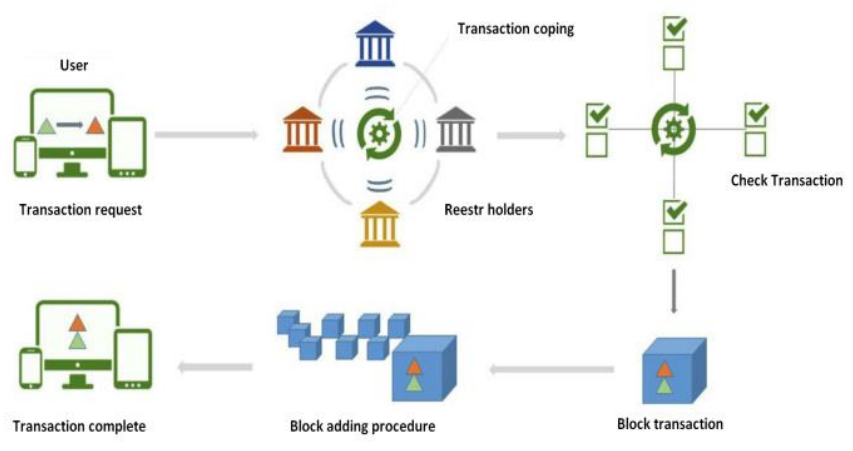

Fig. 3. Standard Blockchain algorithm

At this algorithm using following blocks (see Table).

Block format for Standard Blockchain algorithm

\begin{tabular}{|c|c|c|}
\hline Field & Description & Size \\
\hline BLOCK_ID & Block Identifier & 4 bytes \\
\hline TIME & Time & 4 bytes \\
\hline USER_ID & User Block Identifier & 5bytes \\
\hline LEVEL & Miner level & 2bytes \\
\hline SIGN & $\begin{array}{l}\text { Signature (TYPE, } \\
\text { PREV_BLOCK_HASH, } \\
\text { USER_ID, LEVEL, MRKL_ROOT }\end{array}$ & $\begin{array}{l}128 \\
512 \text { bytes }\end{array}$ \\
\hline TRANSACTIONS & Transactions & Less $3 \mathrm{Mb}$ \\
\hline
\end{tabular}

Cicling request choosing blocks with new information each 120 sec. and modified the chain. In this case we used prescision timing with accuracy $1 \mathrm{~ms}$ from STC KOMSET high prescision time servers, we can make blockcain cicling 100 times faster. There is new Fast Blockchain Algorithm at the Figure 4.

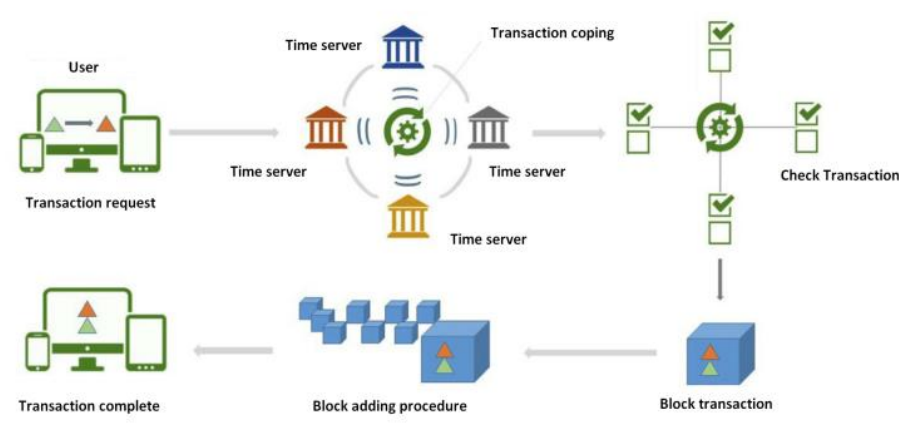

Fig. 4. Fast Blockchain algorithm

Fast Blockchain algorithm can provide more efficient blockchain processing. As the part of tegs, we use time lables from the STC KOMSET servers as was mentioned before.
The certificate of conformity is issued as a result of check in system of certification "Digital Innovations".

\section{CERTIFICATION OF TIMING QUALITY IN} CERTIFICATION SYSTEM "DIGITAL INNOVATIONS"

Certification system "Digital Innovations" purposes are:

- $\quad$ support of the environment of production in which data in a digital form are a key factor of production in all spheres of social and economic activity;

- $\quad$ support of conditions of development of high-tech businesses;

- $\quad$ assistance to prevention of emergence of obstacles and restrictions of development of high-tech businesses;

- $\quad$ support of increase of competitiveness of the russian Federation in the global market.

These purposes require creation of conditions of close interaction of the main key objects:

- the markets and branches of economy where interaction of suppliers and consumers of production and services is carried out;

- platforms and technologies where means for development of the markets and branches of economy are formed;

- creating conditions for development of platforms and technologies and effective interaction of consumers of production and services.

Areas of certification of objects of through digital technologies are:

- $\quad$ systems and objects of the industrial Internet of things;

- $\quad$ systems and objects of the tactile and touch Internet of things;

- components of a robotics and sensorics;

- means and services of technologies of wireless communications;

- means and services of virtual and augmented reality technologies ;

- $\quad$ systems for work with big data;

- systems and objects of neurotechnologies and artificial intelligence;

- $\quad$ systems of the distributed register;

- objects of quantum technologies;

- new production technologies.

Change of the list of such technologies on a measure emergence and developments of new technologies is provided.

Certification of the services directed on support of information infrastructure:

- certification of services of communication networks which provide requirements of economy on collecting and data transmission of the state, business and citizens taking into account the 
technical requirements imposed by digital technologies;

- certification of services of data-processing centers which provides granting to the state, to business and citizens of available, steady, safe and economically effective services in storage and data processing on conditions and allows including to export services in storage and data processing;

- certification of services of digital platforms of work with data for ensuring requirements of the power, business and citizens;

- certification of services of system of collecting, the processing, storage and providing spatial data to consumers providing needs of the state, business and citizens for actual and reliable information about spatial objects.

Prevention of calls and threats:

- $\quad$ the problem of ensuring human rights in the digital world;

- the threats of the personality, to business and the state connected with tendencies to creation of difficult hierarchical information and telecommunication systems;

- building of opportunities of external information and technical impact on information infrastructure;

- growth in computer crime.

\section{CONCLUSION}

In the IoE networks it is necessary to use a uniform time scale.

Timeline accuracy in the IoE networks has to be $1 \mathrm{~ms}$ depending on the transmitted data.

It is expedient to use the distributed mechanism of time synchronization and frequency realized on servers of STC KOMSET to the IoE networks.

The certification mechanism based on algorithm Blockchain is used to synchronize time and frequency.

The certificated quality of time synchronization is issued In system of certification "Digital Innovations". The technique of an assessment is based on Blockchain algorithm that renders it unsuitable for falsification.

\section{REFERENCES}

[1] Указ Президента РФ от 09.05.2017 N 203 «О Стратегии развития информационного общества в Российской Федерации на 2017 2030 годы» [The decree of the president of the Russian Federation "About strategy of development of information society in the Russian Federation for 2017-2030"]. http://www.consultant.ru/document/cons_doc_LAW_216363/.

[2] Распоряжение Правительства РФ от 28.07.2017 N 1632-р «Об утверждении программы "Цифровая экономика Российской Федерации"» [The order of the Government of the Russian Federation of July 28, 2017 No. 1632-r "The Digital Economy of the Russian Federation"]. http://www.consultant.ru/document/cons_doc_LAW_221756/.

[3] Оситис А.П., Мельник С.В., Петрова Е.Н., Смирнов Н.И. Применение добровольной сертификации в целях содействия реализации программы «Цифровая экономика Российской Федерации» // Труды Международной научно-технической конференции «Телекоммуникационные и вычислительные системы -2017». M., 2017. C. 117-122. [Ositis A.P., Melnik S.V., Petrova E.N., Smirnov N. I. Application of voluntary certification for assistance of implementation of the "Digital economy of the Russian Federation" program // International Forum of Informatization (IFI) 2017. International congress "Communication technologies and networks": Collection of works. Moscow, 2017. P. 117-122.

[4] Мельник С.В., Петрова Е.Н., Смирнов Н.И. Технология мобильной связи четвертого поколения LTE. Основные особенности и перспективы внедрения в России // Т-Comm. Телекоммуникации и транспорт. 2012. Т. 4, № 7. С. 89-90. [Melnik S.V., Petrova E.N., Smirnov N.I. Fourth-generation mobile communications technology of LTE The main features and prospects of introduction in Russia // T-Comm: Telecommunications and transport. 2010. T. 4 N 7. P. 89-90].

[5] Аджемов А.С., Смирнов Н.И., Мельник С.В. и др. Пути обеспечения единого точного времени на сетях электросвязи Носсии с использованием ГЛОНАСС // Системы синхронизации, формирования и обработки сигналов. 2013. Т. 4. № 3. С. 150-153. [Adzhemov A.S., Smirnov N. I., Melnik S.V. et al. Ways of ensuring uniform exact time on networks of telecommunication of Russia with use of GLONASS // System of synchronization, formation and processing of signals. 2013. T. 4. N 3. Р. 150-153].

[6] Мишенков С.Л., Мельник С.В., Петрова Е.Н. и др. Обеспечение точного времени для сектей связи с использованием возможнеостей ГНСС ГЛОНАСС или ГЛОНАCC/GPS. Моделирование сетей мобильной связи нового поколения // ТComm. Телекоммуникации и транспорт. 2012. Т. 6. № 9. Р. 102 103. [Mishenkov S. L., Melnik S.V., Petrova E.N., Smirnov N. I. ensuring exact time for communication networks with use of opportunities of GNSS GLONASS or GLONASS/GPS. modeling of networks of mobile communication of new generation // T-Comm: Telecommunications and transport. 2012. T. 6, N 9. P. 102-103].

[7] Мишенков С.Л., Смирнов Н.И., Мельник С.В. и др. Перспективы использования модернизируемой глобальной навигационной спутниковой системы ГЛОНАСС в качестве многофункциональной спутниковой системы // T-Comm. Телекоммуникации и транспорт. 2011. Т. 5, № 9. С. 106-109. [Mishenkov S. L., Smirnov N. I., Melnik S.V. et al. Prospects of use of the modernized global navigation satellite GLONASS system as multipurpose satellite system // T-Comm: Telecommunications and transport. 2011. T. 5, N 9. P. 106-109ъ. 